\title{
Triceps Skinfold Thickness
}

National Cancer Institute

\section{Source}

National Cancer Institute. Triceps Skinfold Thickness. NCI Thesaurus. Code C98793.

A measurement of the thickness of a pinch of skin on the triceps. 